\title{
E-procurement, supplier integration and supply chain performance in small and medium enterprises in South Africa
}

\begin{tabular}{|c|c|}
\hline \multicolumn{2}{|c|}{$\begin{array}{l}\text { Authors: } \\
\text { Jerimiah Madzimure }^{1} \\
\text { Chengedzai Mafini }^{1} \\
\text { Manillal Dhurup }^{2}\end{array}$} \\
\hline \multicolumn{2}{|c|}{$\begin{array}{l}\text { Affiliations: } \\
{ }^{1} \text { Department of Logistics, } \\
\text { Vaal University of Technology, } \\
\text { Vanderbijlpark, South Africa }\end{array}$} \\
\hline \multicolumn{2}{|c|}{$\begin{array}{l}{ }^{2} \text { Center for Academic } \\
\text { Development, Faculty of } \\
\text { Management Sciences, Vaal } \\
\text { University of Technology, } \\
\text { Vanderbijlpark, South Africa }\end{array}$} \\
\hline \multicolumn{2}{|c|}{$\begin{array}{l}\text { Corresponding author: } \\
\text { Chengedzai Mafini, } \\
\text { chengedzai@hotmail.com }\end{array}$} \\
\hline \multicolumn{2}{|c|}{$\begin{array}{l}\text { Dates: } \\
\text { Received: } 06 \text { Nov. } 2019 \\
\text { Accepted: } 18 \text { June } 2020 \\
\text { Published: } 03 \text { Sept. } 2020\end{array}$} \\
\hline \multicolumn{2}{|c|}{$\begin{array}{l}\text { How to cite this article: } \\
\text { Madzimure, J., Mafini, C., } \\
\text { \& Dhurup, M. (2020). } \\
\text { E-procurement, supplier } \\
\text { integration and supply chain } \\
\text { performance in small and } \\
\text { medium enterprises in South } \\
\text { Africa. South African Journal } \\
\text { of Business Management } \\
\text { 51(1), a1838. https://doi.org/ } \\
\text { 10.4102/sajbm.v51i1.1838 }\end{array}$} \\
\hline \multicolumn{2}{|c|}{$\begin{array}{l}\text { Copyright: } \\
\text { (c) 2020. The Authors. } \\
\text { Licensee: AOSIS. This v } \\
\text { is licensed under the } \\
\text { Creative Commons } \\
\text { Attribution License. }\end{array}$} \\
\hline \multicolumn{2}{|l|}{ Read online: } \\
\hline 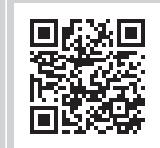 & $\begin{array}{l}\text { Scan this QR } \\
\text { code with your } \\
\text { smart phone or } \\
\text { mobile device } \\
\text { to read online. }\end{array}$ \\
\hline
\end{tabular}

Purpose: With rapid changes in technology and the globalisation of markets, firms, especially small to medium enterprises (SMEs), require support to adapt to technology and make use of e-procurement functions to develop competitive advantages. Information systems such as e-procurement have become increasingly linked with other business activities such as supply chain integration to initiate the growth of SMEs. This study investigated the relationship between e-procurement, supplier integration and supply chain performance in retail SMEs in South Africa.

Design/methodology/approach: A quantitative research approach was followed in which a sample of 283 owners and managers of SMEs in Gauteng Province, South Africa, were surveyed using a structured questionnaire. The study considered five e-procurement components, namely e-sourcing, e-negotiation, e-informing, e-design and e-evaluation. The collected data were analysed using structural equation modelling.

Findings/results: The results of the study showed that two e-procurement components, namely e-design and e-negotiation, exerted a significant positive influence on supply chain integration. The other three e-procurement components, namely e-sourcing, e-evaluation and e-informing, were statistically insignificant in influencing supply chain integration. The study further revealed that supplier integration exerts a positive and significant linear relationship with both the tangible and intangible dimensions of supply chain performance (SCP).

Practical implications: Retail SMEs may refer to this study for information regarding which components of e-procurement deserve primary attention when implementing such systems and how these may be harnessed for the improvement of SCP.

Originality/value: The study represents a pioneering attempt to model the nexus between e-procurement, supplier integration and the performance of retail supply chains within South African SMEs. It provides the foundation for future research studies on the implementation of e-procurement and other digitalised supply chain practices in various sectors of the South African economy.

Keywords: e-procurement; supplier integration; supply chain performance; small to medium enterprises; South Africa.

\section{Introduction and background to the study}

In South Africa and other developing countries, most small to medium enterprises (SMEs) continue to face countless challenges that deter their growth and performance. Such challenges range from the effects of technology, globalisation and liberalisation to poor networking amongst the important players in the market and stiff competition from established firms (Gumboh \& Gichira, 2015; Pooe, Mafini, \& Loury-Okoumba, 2015; Sibanda \& Manda, 2016). These challenges tend to stifle many business activities, including inhibiting collaboration amongst business partners, which consequently affects SME performance. In particular, the lack of appropriate technology has been cited as an impediment to SME collaboration, innovation and growth (Nguyen, 2009; Steyn \& Leonard, 2012). To overcome such problems, many SMEs have shifted to the use of technologies such as Internet-based business platforms in the quest to improve efficiency and effectiveness (Basheka, Oluka, \& Mugurisi, 2011; Fernandes \& Vieira, 2015; Makien, Kahkonen, \& Lintukangas, 2011). The embracing of such initiatives has provided SMEs with competitive advantages that enable them to compete with larger firms (Nugroho, Susilo, Fajar, \& Rahmawati, 2017).

With the continued rapid growth of technology and the globalisation of markets, Internet-based systems such as e-procurement and supply chain integration have become important to the successful implementation of supply chain management (SCM), especially in SMEs in developing 
countries such as South Africa (Hassan, Tretiakov, Whiddett, \& Adon, 2014). It has been commonly accepted that information infrastructure such as e-procurement has become increasingly connected and embedded with other activities such as supply chain integration to initiate the growth of SMEs (Vaast \& Walsham, 2017). The application of various e-procurement functions as well as timeous integration with suppliers may result in the positive supply chain performance (SCP) of a firm and is also considered as an innovation strategy action (Mishra \& Agarwal, 2010). Most SMEs undertake efforts to compete on multiple fronts, which include implementation of e-procurement and supplier integration to improve SCP (Maiga, 2016). Hence, many of them have found value in investing in information technology (IT) infrastructure to automate and streamline their internal business processes.

This study aimed to investigate the relationship between e-procurement, supplier integration and SCP in SMEs operating in the retail sector in South Africa. In the past several years, there has been a growing interest in the strategic importance of integrating suppliers as well as implementing e-procurement (Antony, 2018; Ibem \& Laryea, 2015). Current knowledge involving the application of e-procurement, as well as supplier integration, in SMEs in developing countries is still limited, thereby creating a need for greater understanding of the nature of practice between these constructs as increasing competition puts pressure on firms (Boehmke \& Hazen, 2017).

Within South Africa, the government is increasingly adopting and encouraging e-procurement in SMEs, in line with the objectives of the National Development Plan (NDP) 2030 vision, which include innovation, employment creation and the adoption of technology as mechanisms for the economic development of the country (Zarenda, 2013). The South African government is eager to develop and streamline SME operations because SMEs have emerged as important contributors to the economy.

Notably, most studies on e-procurement, supplier integration and SCP have focused on large companies (Chang Tsai, \& Hsu, 2013). Moreover, a comprehensive literature search conducted by the authors revealed a general lack of studies that have examined the relationship between e-procurement, supplier integration and SCP in SMEs in South Africa. Although there are studies dedicated to SMEs and e-procurement in other regions of the world (e.g. Chan \& Lee, 2003; Fernandes \& Viera, 2015; Flynn \& Davis, 2016; Hassan et al., 2014; Ngui, 2016), the literature does not provide any structured research about this subject in the context of South Africa. In addition, although research on e-procurement and SCP has focused on specific industries such as health, hospitality, manufacturing, service and technology-based industries (Njagi \& Ogutu, 2014), the focus on retail SMEs has been minimal (Zhao, Feng, \& Wang, 2015). Furthermore, the impact of the antecedents to SME performance has received little attention in empirical research (Georgise, Thoben, \& Seifert, 2014; Pooe \& Mahlangu, 2017). This study is intended to address these gaps by investigating the relationship between e-procurement, supplier integration and SCP in retail SMEs in South Africa.

This study focused on the retail SME industry because it is a significant contributor to technical innovation and new product development (Ou, 2006:89). Moreover, the retail and wholesale sectors contribute $25 \%$ of the national gross domestic product (GDP) of South Africa (Dennis \& Piatti, 2015; Sibindi \& Aren, 2015). Therefore, retail SMEs are essential for the growth of the South African economy, which, in turn, provides an impetus to conduct a study in this very important sector of the economy.

\section{Literature review}

\section{Small and medium enterprises in South Africa}

The National Small Business Act (No. 26 of 1996) of South Africa, as amended in 2003, defines an SME as a separate and distinct business managed by one owner or more, including its branches or subsidiaries, if any. Typically, SMEs are found in any sector or subsector of the economy mentioned in the schedule of size standards and can be classified as such by satisfying the criteria specified in the schedule of size standards. According to the National Small Business Act (No. 26 of 1996) of South Africa, as amended in 2003 (Government Gazette Republic of South Africa, 2003), a small business in South Africa is one that employs 50 people or less and has a total turnover of up to R19million, with a total asset value of R3m. A medium business employs between 50 and 200 people and has a total turnover of R39m with a total asset value of R6m.

In South Africa, SMEs perform a critical role in the country's economy. They contribute to approximately $50 \%$ of the country's GDP and up to $60 \%$ of the overall employment in South Africa (Abor \& Quartey, 2010; Doern, 2009; SME South Africa, 2017). However, the performance of SMEs in South Africa remains depressed, and the country has one of the highest SME failure rates in comparison to other developing nations (Leboea, 2017). The reasons behind these failures are multifaceted and include the lack of access to financial capital, lack of entrepreneurial and business skills, lack of innovation, a poorly performing and unsupportive national economy, crime, corruption, technological changes and other unpredictable market-related dynamics (Chimucheka \& Rungani, 2011; Urban \& Naidoo, 2012). This study presupposes that the implementation of advanced technologies such as e-procurement systems could be a lasting panacea to such challenges.

\section{E-procurement}

There is no single universally accepted definition of e-procurement. However, in this study, it is perceived as the use of information technologies to facilitate business-tobusiness transactions for materials and services $(\mathrm{Wu}, 2007)$. E-procurement activities include enterprise resource planning (ERP); e-maintenance, repair and operations (E-MRO); e-sourcing; e-tendering; e-reverse auctioning; 
e-informing and e-market-places (Smuts, 2008). According to McCue and Roma (2012), tools such as e-notices, e-auctions, e-catalogues, e-dossiers, e-submissions and e-signatures are components of e-procurement. This study is based on e-sourcing, e-design, e-informing, e-negotiation and e-evaluation, which are the major functions through which e-procurement contributes to supplier integration and SCP (Hugos, 2011). Brief descriptions of these e-procurement components are provided below:

- E-sourcing: This refers to the process of finding new potential suppliers using Internet technologies, with the aim of decreasing search costs (Lysons \& Farrington, 2012; Ombat, 2015). It merely uses a Web-based platform to support all steps in the sourcing process, including expenditure analysis, demand aggregation, requirements definition, supplier discovery, negotiations (request for indent, proposal or quotation), reverse auctions, bid evaluations and contract management.

- E-design: This refers to the setting of purchasing requirements on an online procurement system (Chang et al., 2013). E-design facilitates supplier involvement in the specification development process of a product.

- E-informing: This refers to the gathering and distributing of purchasing information both from and to internal and external parties using Internet technology, for example, purchasing management information on an extranet that can be accessed by internal clients and suppliers (Sharma, 2012). In other words, e-informing involves information gathering, information distribution and purchasing information (Corina, 2011; Ombat, 2015).

- E-negotiation: This refers to the process of conducting negotiations between business partners using electronic means (Rinderle-ma, 2005). Thus, e-negotiation is used to make significant savings in the purchase of goods and services via the Internet (Scot \& Morrison, 2007).

- E-evaluation: This refers to the stage where extensive information about suppliers is collected for further evaluations and transactions via the Internet (Chang \& Wong, 2012). According to Presutti (2003:231), an organisation implementing e-procurement tools must evaluate and improve its purchasing process to achieve full benefits.

Application of e-procurement functions yields manifold benefits to organisations, ranging from time and cost savings, faster order fulfilment, reduced purchasing cycle time, enhanced budgetary control, elimination of administrative errors, increase in buyer productivity and decrease in prices through standardisation and consolidation of purchasing power and better information management (Baily, Farmer, Crocker, Jessop, \& Jones, 2008; Cameron, 2007; Wisner, Tan, \& Leong, 2012).

\section{Supplier integration}

Supplier integration refers to the process of interaction and collaboration between the firm and its suppliers to ensure the adequate flow of supplies (Das, Narasimhan, \& Talluri, 2006; Flynn, Huo, \& Zhao, 2010; Germain \& Iyer, 2006; Narasimhan
\& Peters, 2010; Petersen, Handfield, \& Ragatz, 2005; Zhao, Huo, Selen, \& Yeung, 2011). Supplier integration is also regarded as the development of a long-term relationship between a firm and its suppliers (Li, Rangu-Nathan, RanguNathan \& Rao, 2006). It is this partnership or integration that forms the essential building blocks of SCM (Walters, 2009). Scores of researchers have cited the benefits of supplier integration in SMEs.

For instance, most SMEs continuously face the problem of ontime delivery (Zhao et al., 2015). However, through integration with suppliers, SMEs can share order and inventory information with suppliers. Furthermore, supplier integration, which includes suitable communication, sharing information and working together with suppliers, can reduce upstream complexity (Zhao et al., 2015). The benefits of supplier integration are that it enhances responsiveness, flexibility and time savings (Chen, Yang, \& Li, 2007; Fawcett, Osterhaus, Magnan, Brau, \& Mccarter, 2007; Leopoulos et al., 2007; Li \& $\mathrm{Li}, 2005)$. Supplier integration also plays a role in reducing transaction costs through the reduction of uncertainties and reducing production costs (Flynn et al., 2010), which leads to enhanced operational performance (Yu, Chavez, Feng, \& Wiengarten, 2014). In supplier integration, opportunistic behaviours are significantly reduced under shared visions and cooperative goals (Prajogo, Oke, \& Olhanger, 2015; Wong, Tjosvold, \& Yu, 2005).

\section{Supply chain performance}

Srinivasan, Mukherjee and Gaur (2011) defined SCP as the performance of various processes included within the firm's supply chain function. One of the key aspects of successful SCP is cooperation and mutual decision-making between trading partners (Botta-Genoulaz, Campagne, Llerena, \& Pellegrin, 2010; George, Williams, \& Henthrone, 2011). Businesses try to improve their industrial performance in terms of cost, delays, adaptability, variety and traceability. Collaboration practices and information exchanges between partners become essential within any supply chain, as they contribute to performance (Sakka \& Botta-Genoulaz, 2009). Effective performance measurement is critical for SCP because it provides the basis to understand the system as well as information about the results of systematic efforts to supply chain partners (Bhagwat \& Sharma, 2007; Chen et al., 2007). Overall, SCP is recognised as an essential factor for improving competitive advantage (Amaratunga \& Baldry, 2002; Das et al., 2006; Chang et al., 2013).

Because SCP is a multidimensional concept, various frameworks have been proposed that define these boundaries. Beamon (1999) identified three measures - resources, output and flexibility - as important elements in assessing the SCP for an organisation. Gunasekaran, Patel and Tirtiroglu (2001) presented a framework based on three SCP measurement levels (strategic, tactical and operational). Another model of SCP was proposed by Chan and Qi (2003), which categorises the measurement into two distinct phases: quantitative and qualitative. Still, SCP may be measured through the Supply 
Chain Operations Reference (SCOR) model developed by the Supply Chain Council, which uses the plan, source, make, deliver and return processes on which all supply chain processes are based (Huan, Sheoran, \& Wang, 2004). This study is based on a model developed by Chang et al. (2013), which divides SCP into tangible and intangible dimensions. Tangible dimensions are those that include the evaluation of SCM factors such as costs, profits and cash turnover, whereas intangible dimensions are those that include the evaluation of SCM factors such as capacity utilisation, customer satisfaction and lead time.

\section{Conceptual framework and hypotheses}

This study is based on the conceptual framework presented in Figure 1. In the framework, e-procurement is presented as the predictor variable and has five dimensions, namely, e-design, e-sourcing, e-negotiation, e-evaluation and e-information. The mediating construct is supplier integration, leading to SCP, which has two dimensions, namely, tangible and intangible SCP.

The five forms of e-procurement, namely, e-sourcing, e-design, e-informing, e-negotiation and e-evaluation, have emerged as important elements of e-procurement in the SCM field. E-procurement is increasingly recognised as an effective tool to reduce purchasing costs and streamline processes. To continually succeed in the market, especially SMEs, the e-procurement concept has become vital, as competition is no longer amongst firms but amongst supply chains as well. The other benefits of e-procurement to a firm include reducing order cycle times (Gunesekaran \& Ngai, 2008; Liu, Sun, Wang, \& Zhao, 2011; Tatsis, Mena, Van Wassenhove, \& Whicker, 2006); expanding supplier bases (Moon, 2005); reducing paperwork (Gunesekaran \& Ngai, 2008); eliminating order errors (Mettler \& Rohner, 2009; Zheng et al., 2016); improving productivity and/or service (Gunasekaran, McGaughey, Ngai, \& Rai, 2009); improving the effectiveness of the purchasing process (Panayioutou, Gayilas, \& Tatsiopoulos, 2004) and reducing the purchase department size and the number of functional areas involved in the purchasing process (Ronchi, Brun, Golini, \& Fan, 2010). In addition, Chang and Wong (2012)

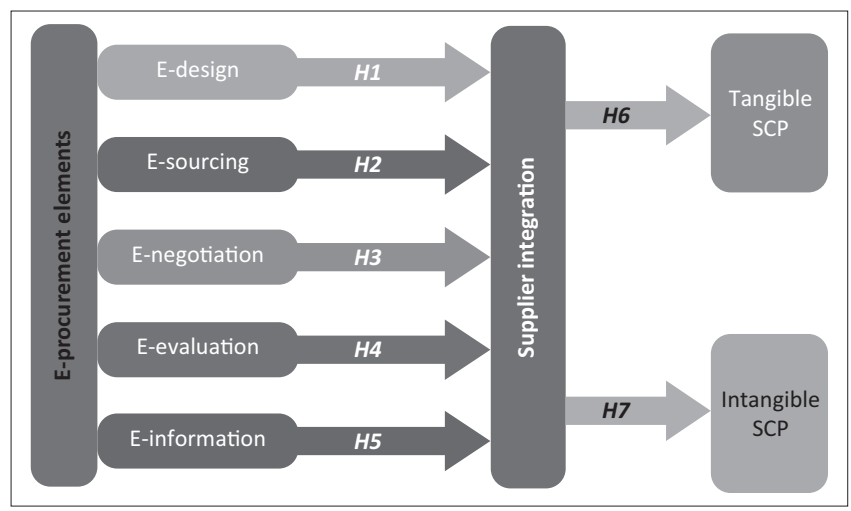

SCP, supply chain performance.

FIGURE 1: Conceptual framework for the study: E-procurement and supplier integration. found that e-procurement generated higher levels of partnership and improved SCP. Shank and Brown (2007) also found that successful companies or firms using e-procurement systems effectively ultimately lead to greater supplier integration. These insights lead to the following hypotheses:

H1: E-design positively influences supplier integration in the SME sector.

H2: E-sourcing positively influences supplier integration in the SME sector.

H3: E-negotiation positively influences supplier integration in the SME sector.

H4: E-evaluation positively influences supplier integration in the SME sector.

H5: E-informing positively influences supplier integration in the SME sector.

\section{Supplier integration and supply chain performance}

It is suggested that as a result of integration within firms, positive organisational performance might be enhanced by sharing risks and business information, which includes demand forecasts, inventory level and production planning decisions, as well as synchronising business processes (So \& Sun, 2010). The relationships between integration and SME performance have been extensively studied (Kim, 2009; Kristal, Huang, \& Roth, 2010; Lau, Yam \& Tang, 2007), and these findings confirm that integration can be transformed into competitive capabilities, thus contributing to positive SCP. Moreover, several studies (Bowersox, Closs, \& Stank, 1999; Childerhouse \& Towill, 2003; Flynn et al., 2010; Frohlich \& Westbrook, 2001; Gimenez \& Ventura, 2005; Thietart, 2007; Zhao et al., 2011) confirmed the positive relationship between supplier integration and SCP, which shows convincing empirical evidence for the relationship between these two constructs. The present study was intended to confirm or dispute the results presented in such previous research. Hence, the following hypotheses are presented:

H6: Supplier integration positively influences tangible SCP in the SME sector.

H7: Supplier integration positively influences intangible SCP in the SME sector.

\section{Research methodology Research approach}

In this study, a quantitative research approach was adopted; this approach was considered the most appropriate because addressing the research problem depended on the analysis of quantitative data collected on many survey questions around e-procurement, supplier integration and SCP in SMEs. Moreover, a quantitative approach was followed because the study was testing the causal relationships or influence of e-procurement on supplier integration and SCP amongst SMEs. 


\section{Sampling design}

The target population was composed of SMEs operating in Gauteng Province, South Africa. The actual number of SMEs in Gauteng Province is not known, although a report by Statistics South Africa (2015) estimated that there were at least 687556 SMEs in Gauteng Province in 2015. Because the actual number of SMEs operating in the province is elusive, it was difficult to find a single sampling frame from which a list of SMEs in Gauteng Province could be found. To identify SMEs for inclusion in this study, an extensive Internet search was conducted using keywords such as 'contacts/number of SMEs in Gauteng Province'. From this search, approximately 1993 formal retail SMEs that indicated that they were using e-procurement were identified from the different sectors of the economy. These retail SMEs were subsequently contacted through email and telephonically to request permission to conduct this current study. Out of this number of SMEs in the province, 350 questionnaires were distributed. A total of 294 questionnaires were returned, and 11 were discarded because of incomplete responses to different parts of the questionnaire, culminating in 283 questionnaires that were eventually used in the study.

To determine whether this sample size was adequate, reference was given to recommendations from the literature. For instance, Pallant (2007) stated that the overall sample size in a quantitative study should be at least 150 elements. Tabachnick and Fidell (2007) also suggest that it is important to have at least 200 cases for multivariate analysis. Based on these recommendations, the sample size $(n=283)$ used in this study was considered to be adequate. The actual selection of participating retail SMEs was conducted by using the convenience sampling technique because there was no single sampling frame from which the list of these businesses could be obtained. Each participating SME provided one respondent, who was either the owner or a manager.

An analysis of the profile of the 283 SMEs that participated in the study revealed that $45 \%$ had $151-200$ employees, whereas $38 \%$ had $101-150$ employees. At least $28 \%$ of the SMEs had an annual turnover of R20m - R30m, whereas an estimated 37\% had an annual turnover of R30m - R39m.

\section{Measurement instrument}

The measurement scales used in this study were operationalised from previous research. The five e-procurement elements (e-sourcing, e-design, e-negotiation, e-evaluation and e-informing) were measured by using a 22-item scale adapted from Chang et al. (2013) and Ombat (2015). Supplier integration was measured by using eight items adapted from Zhao, Huo, Sun and Zhao (2013). The two dimensions of SCP were measured by using a 10-item scale adapted from Chang et al. (2013). Following the argument of Wegner (2012), most of the questions contained in the survey questionnaire were Likert-type scale questions to reduce the development of response bias amongst the respondents and to standardise the response options so that they could be comparable amongst the respondents.

\section{Data collection}

For the collection of data, a cross-sectional survey design was followed, which involved the once-off distribution of questionnaires to targeted respondents without repeating the process. The questionnaires were distributed in person by the principal researcher over 3 months between May and July 2017. Because the geographic area (Gauteng Province) to be covered for the data collection was wide, three trained field workers were employed as research assistants.

\section{Data analysis}

Data were subjected to statistical analysis using the Statistical Package for Social Sciences (SPSS) version 25.0 and the Analysis of Moment Structures (AMOS) version 25.0. The respondents' biographical information and the composition of the sample were analysed using descriptive statistics in the form of frequencies, whereas inferential statistics were used to test the hypotheses.

\section{Measurement scale accuracy assessment}

This study employed the structural equation modelling (SEM) approach, recommended by (Andersen \& Gerbing 1988), to analyse the inferential statistics. The SEM procedure is defined as a confirmatory, multivariate technique that looks at causal relationships between variables in a diagrammatic form (Foster, Barkus, \& Yavorsky, 2006). The procedure involves two phases: firstly, the assessment of scale accuracy using a confirmatory factor approach (CFA), followed by the testing of the hypotheses using the path analysis technique. The CFA procedure assesses how well the variables that were measured represent a smaller number of constructs (Hair, Black, Babin, \& Anderson, 2014). In this study, the CFA procedure was conducted to assess the psychometric properties of the measurement scales. This included testing for the reliability, validity and model fit of the measurement items of the study. The results of the CFA are reported in Table 1.

Reliability was tested using a combination of the Cronbach alpha coefficient, the composite reliability (CR) and itemtotal correlations. The CR for each scale was calculated using the following formula (Eqn 1), which was recommended by Fornell and Larcker (1981):

$(\mathrm{CR}): \mathrm{CR} \eta=(\Sigma \lambda y i)^{2} /\left[(\Sigma \lambda y i)^{2}+(\Sigma \varepsilon i)\right]$

[Eqn 1]

Composite reliability $=$ (square of the summation of the factor loadings) $/$ (square of the summation of the factor loadings $)+$ (summation of error variances $)\}$. 
TABLE 1: Accuracy analysis statistics: Reliability tests.

\begin{tabular}{|c|c|c|c|c|c|c|c|c|c|}
\hline \multirow[t]{2}{*}{ Research construct } & \multirow[t]{2}{*}{ Item } & \multicolumn{2}{|c|}{ Descriptive statistic } & \multicolumn{2}{|c|}{ Cronbach test } & \multirow[t]{2}{*}{ CR } & \multirow[t]{2}{*}{ AVE } & \multirow[t]{2}{*}{ Factor loading } & \multirow[t]{2}{*}{ Highest SV } \\
\hline & & Mean & SD & Item total & Alpha value & & & & \\
\hline \multirow[t]{6}{*}{ E-design } & - & 4.62 & 0.56 & - & 0.71 & 0.88 & 0.60 & - & 0.47 \\
\hline & ED 1 & - & - & 0.53 & - & - & - & 0.57 & - \\
\hline & ED 2 & - & - & 0.48 & - & - & - & 0.48 & - \\
\hline & ED 3 & - & - & 0.4 & - & - & - & 0.54 & - \\
\hline & ED 4 & - & - & 0.48 & - & - & - & 0.59 & - \\
\hline & ED 5 & - & - & 0.46 & - & - & - & 0.58 & - \\
\hline \multirow[t]{5}{*}{ E-sourcing } & - & 4.68 & 0.53 & - & 0.75 & 0.94 & 0.79 & - & 0.58 \\
\hline & ES 1 & - & - & 0.51 & - & - & - & 0.61 & - \\
\hline & ES 2 & - & - & 0.59 & - & - & - & 0.73 & - \\
\hline & ES 3 & - & - & 0.62 & - & - & - & 0.69 & - \\
\hline & ES 4 & - & - & 0.49 & - & - & - & 0.61 & - \\
\hline \multirow[t]{4}{*}{ E-negotiation } & - & 4.7 & 0.54 & - & 0.72 & 0.88 & 0.84 & - & 0.66 \\
\hline & EN 1 & - & - & 0.51 & - & - & - & 0.63 & - \\
\hline & EN 2 & - & - & 0.65 & - & - & - & 0.79 & - \\
\hline & EN 3 & - & - & 0.55 & - & - & - & 0.68 & - \\
\hline \multirow[t]{6}{*}{ E-evaluation } & - & 4.78 & 0.45 & - & 0.77 & 0.78 & 0.71 & - & 0.52 \\
\hline & EE 1 & - & - & 0.42 & - & - & - & 0.49 & - \\
\hline & EE 2 & - & - & 0.62 & - & - & - & 0.77 & - \\
\hline & EE 3 & - & - & 0.59 & - & - & - & 0.76 & - \\
\hline & EE 4 & - & - & 0.5 & - & - & - & 0.49 & - \\
\hline & EE 5 & - & - & 0.56 & - & - & - & 0.58 & - \\
\hline \multirow[t]{6}{*}{ E-informing } & - & 3.89 & 0.78 & - & 0.72 & 0.77 & 0.66 & - & 0.47 \\
\hline & El 1 & - & - & 0.5 & - & - & - & 0.61 & - \\
\hline & El 2 & - & - & 0.49 & - & - & - & 0.62 & - \\
\hline & El 3 & - & - & 0.52 & - & - & - & 0.65 & - \\
\hline & El 4 & - & - & 0.46 & - & - & - & 0.55 & - \\
\hline & El 5 & - & - & 0.41 & - & - & - & 0.48 & - \\
\hline \multirow[t]{9}{*}{ Supplier integration } & - & 4.46 & 0.99 & - & 0.89 & 0.88 & 0.84 & - & 0.57 \\
\hline & SI 1 & - & - & 0.52 & - & - & - & 0.55 & - \\
\hline & $\mathrm{SI} 2$ & - & - & 0.64 & - & - & - & 0.65 & - \\
\hline & $\mathrm{SI} 3$ & - & - & 0.7 & - & - & - & 0.67 & - \\
\hline & $\mathrm{SI} 4$ & - & - & 0.72 & - & - & - & 0.79 & - \\
\hline & SI 5 & - & - & 0.7 & - & - & - & 0.79 & - \\
\hline & SI 6 & - & - & 0.69 & - & - & - & 0.72 & - \\
\hline & SI 7 & - & - & 0.7 & - & - & - & 0.68 & - \\
\hline & SI 8 & - & - & 0.66 & - & - & - & 0.68 & - \\
\hline \multirow[t]{5}{*}{ Tangible dimension } & - & 4.36 & 0.65 & - & 0.78 & 0.93 & 0.82 & - & 0.61 \\
\hline & TD 1 & - & - & 0.53 & - & - & - & 0.57 & - \\
\hline & TD 2 & - & - & 0.53 & - & - & - & 0.58 & - \\
\hline & TD 3 & - & - & 0.67 & - & - & - & 0.82 & - \\
\hline & TD 4 & - & - & 0.63 & - & - & - & 0.78 & - \\
\hline \multirow[t]{7}{*}{ Intangible dimension } & - & 4.79 & 0.45 & - & 0.79 & 0.79 & 0.71 & - & 0.50 \\
\hline & ID 1 & - & - & 0.43 & - & - & - & 0.51 & - \\
\hline & ID 2 & - & - & 0.59 & - & - & - & 0.60 & - \\
\hline & ID 3 & - & - & 0.48 & - & - & - & 0.45 & - \\
\hline & ID 4 & - & - & 0.63 & - & - & - & 0.69 & - \\
\hline & ID 5 & - & - & 0.56 & - & - & - & 0.69 & - \\
\hline & ID 6 & - & - & 0.6 & - & - & - & 0.73 & - \\
\hline
\end{tabular}

SD, standard deviation; $C R$, composite reliability; AVE, average variance extracted; SV, shared variance; ED, e-design; ES, e-sourcing; EN, e-negotiation; EE, e-evaluation, EI, e-informing; SI, supplier integration; TD, tangible dimension; ID, intangible dimension.

For the Cronbach alpha coefficient and the CR, the recommended values should be greater than or equal to 0.70 for each scale (Babbie, 2013; Hair, Bush, \& Ortinau, 2000; Hair, Babin, Anderson, \& Tatham, 2010; Martin, 2007, p. 93), whereas the item-total correlations should be greater than 0.4 (Anderson \& Gerbing, 1988; Dunn, Seaker \& Waller, 1994). As presented in Table 1, the values of the Cronbach alpha and the $\mathrm{CR}$ for all of the measurement scales were higher than the 0.7 cut-off value. Likewise, the item-total correlations for all measurement scales were greater than the recommended minimum threshold of 0.4 . These scores indicate that the reliability of the measurement scales used in this study was satisfactory.

In testing for reliability, the study considered three types of reliability, namely, face validity, content validity and construct validity, the latter of which was represented by its two variants (convergent and discriminant validities). 
TABLE 2: Results of hypothesis testing.

\begin{tabular}{|c|c|c|c|c|c|c|}
\hline Proposed path & Hypothesis & Path coefficient & Standard error & Critical region $t$-value & $\bar{p}$ & Decision \\
\hline E-design $\rightarrow$ supplier integration & $\mathrm{H} 1$ & 0.33 & 0.153 & 2.126 & $<0.05 * *$ & Supported \\
\hline E-sourcing $\rightarrow$ supplier integration & $\mathrm{H} 2$ & 0.31 & 0.204 & 1.572 & $>0.1^{\text {ns }}$ & Not supported \\
\hline E-negotiation $\rightarrow$ supplier integration & $\mathrm{H} 3$ & 0.175 & 0.103 & 1.969 & $<0.1^{*}$ & Supported \\
\hline E-evaluation $\rightarrow$ supplier integration & $\mathrm{H} 4$ & -0.018 & 0.143 & -0.123 & $>0.1^{\mathrm{ns}}$ & Not supported \\
\hline E-informing $\rightarrow$ supplier integration & $\mathrm{H} 5$ & -0.002 & 0.079 & -0.023 & $>0.1^{\text {ns }}$ & Not supported \\
\hline Supplier integration $\rightarrow$ tangible SCP & $\mathrm{H} 6$ & 0.287 & 0.057 & 5.000 & $<0.001 * * *$ & Supported \\
\hline Supplier integration $\rightarrow$ tangible SCP & $\mathrm{H} 7$ & 0.22 & 0.046 & 4.810 & $<0.001 * * *$ & Supported \\
\hline
\end{tabular}

$* * *, p<0.001 ; * *, p<0.05 ; *, p<0.1 ; \mathrm{ns}$, insignificant $(p>0.1)$.

Note: Structural model fits: $\frac{X^{2}}{d f}=1.46 ; \mathrm{IFI}=0.92 ; \mathrm{TLI}=0.91 ; \mathrm{CFI}=0.92 ; \mathrm{RMSEA}=0.04$.

SCP, supply chain performance; IFI, incremental fit index; TLI, Tucker-Lewis index; CFI, comparative fit index; RMSEA, root-mean-square error of approximation.

To test for face validity, the questionnaire was reviewed by two academics whose research interests lie within SCM. To test for content validity, a pilot study was conducted using a targeted sample group of 42 respondents drawn from various SMEs in Gauteng Province. Using the feedback from both the reviewers and the pilot study, two items each were discarded from the e-design, e-sourcing, e-negotiation and intangible SCP scales, whereas four items were discarded from the tangible SCP scale to improve the scale reliability.

Convergent validity was verified by using a combination of factor loadings for the individual scale items and average variance extracted (AVE) values for each scale. To compute the AVE for each scale, a formula (Eqn 2) proposed by Fornell and Larcker (1981) was applied:

$V \eta=\Sigma \lambda y i^{2} /\left(\sum \lambda y i^{2}+\Sigma \varepsilon i\right)$

[Eqn 2]

AVE $=\{$ (summation of the square of factor loadings $) /$ \{(summation of the square of factor loadings) + (summation of error variances)\}.

As revealed in Table 1, all the factor loadings were above the recommended 0.40 cut-off value (Anderson \& Gerbing, 1988; Sin, Tse, Heung, \& Yim, 2005). Convergent validity was also confirmed, as all the AVE values were above the recommended 0.5 (Fornell \& Larcker, 1981; Fraering \& Minor, 2006; Sanders, 2007). These results show that all individual items (observed variables) were converging well on their respective latent variables; hence, the convergent validity was considered to be acceptable.

The first step in testing for discriminant validity was to check whether all AVE values were less than 1. As illustrated in Table 1, all AVE values ranged from 0.45 to 0.51 and were all below 1, which confirms that the indicators of different constructs were diverging (Sin et al., 2005). The second step in establishing discriminant validity was to check whether the highest shared variance (HSV) for each scale was less than the corresponding AVE value for that scale. The HSV is a square of the highest correlation between different latent constructs. The values in Table 1 indicate that all HSV values were less than the AVE values for their respective latent variables, thereby further confirming that the measures of the seven different variables were indeed distinct and heterogeneous (Fornell \& Larcker, 1981).

\section{Model fit assessment}

'Model fit' refers to the extent to which a hypothesised model is consistent with the data (Pallant, 2007). In this study, model fit was ascertained by using the following indices: chi-square value/degrees of freedom $(d f)$, comparative fit index (CFI), incremental fit index (IFI), Tucker-Lewis index (TLI) and the root-mean-square error of approximation (RMSEA). The acceptable thresholds should be equal to or higher than 0.90 for the CFI, IFI, and TLI; for the chi-square value/degrees of freedom, a ratio of 3:1 or less is recommended, and the RMSEA value should be equal to or less than 0.08 (Byrne, 2013).

The results for the model fit tests for the CFA showed an acceptable chi-square value of $1.49\left(\chi^{2} / d f=1046.592 / 702\right)$. Values of the IFI (0.91), TLI (0.91) and CFI (0.91) were all higher than the recommended minimum threshold of 0.9 . The value of the RMSEA was 0.04 , which is also lower than the recommended highest cut-off value of 0.08 . These results indicate an overall good fitness of the CFA model to the specified sample data (Chinomona, Lin, Wang, \& Cheng, 2010).

\section{Results for the hypothesis tests}

The hypotheses were tested by using the path analysis procedure, which is a method of organising and illustrating relationships in data, thereby making it easier to comprehend or 'see' relationships compared to portraying similar information in a matrix (Foster et al., 2006). The model fit was also tested for the structural model to determine its goodness of fit (Little, 2013). A chi-square/ degrees of freedom value of $1.46\left(\chi^{2} / d f=1038.610 / 711\right)$ was reported, which was indicative of a good model fit. Moreover, the values obtained for the other fit indices - IFI (0.92), TLI (0.91), CFI (0.92) and RMSEA (0.04) - were all within the recommended thresholds. The results of the hypothesis tests are presented in Table 2.

\section{Discussion}

This study aimed to examine the relationships between e-procurement practices, supplier integration and SCP in 
South African SMEs. The study tested seven hypotheses proposing the existence of relationships between the constructs. The data collected for the study were tested using the path analysis technique.

The first hypothesis (H1) of the study suggested that e-design exerts a positive influence on supplier integration. As shown in Table 2, H1 was supported because e-design has a positive and significant linear relationship with supplier integration. A positive path coefficient $(\beta=0.33 ; t=2.126 ; p>0.05)$ validates the hypothesised positive relationship. These results imply that SMEs that effectively implement e-design systems increase their chances of integrating and collaborating with their suppliers, which may result in the minimisation of supply chain costs, thus consequently improving SCP. These results further suggest that supply chain member SMEs that invest in and use e-design tools for their buying and selling with each other can learn collectively and create a strong supplier integration.

The second hypothesis (H2) of the study suggested that e-sourcing exerts a positive influence on supplier integration. The results in Table 2 indicate that $\mathrm{H} 2$ was not supported because the path coefficient (beta) was statistically insignificant $(\beta=0.31 ; t=1.572 ; p>0.01)$. The insignificance could be attributed perhaps to the fact that SMEs in South Africa are not yet fully utilising e-procurement systems such as e-sourcing effectively in selecting their suppliers to improve their collaboration with supply chain member firms. Thus, the results of this study suggest that the majority of SMEs surveyed are not collaborating in selecting their suppliers electronically.

The third hypothesis (H3) of the study suggested that e-negotiation exerts a positive influence on supplier integration. The results of the study, as reflected in Table 2, reveal that $\mathrm{H} 3$ was supported because e-negotiation had a positive and significant relationship with supplier integration $(\beta=0.175 ; t=1.969 ; p<0.1)$. Conceivably, the positive relationship may be linked to the increased collaboration that occurs as firms and their suppliers negotiate their contract agreements. Typically, these negotiations take place through electronic means, given the rise of electronic means of communication today (Cano \& Baena, 2015). Such contract agreements may, in turn, improve relations in business and thus contribute to higher levels of engagement, consequently improving SCP (Jean, Sinkovics, \& Cavusgil, 2010). Thus, as posited in $\mathrm{H} 3$, this study suggests that in the SMEs surveyed, there are some contract negotiations taking place with suppliers, and modern technology is used to facilitate them.

The fourth hypothesis (H4) of the study posited that e-evaluation exerts a positive influence on supplier integration. As noted in Table 2, this hypothesis was not supported because e-evaluation has a weak negative $(\beta=-0.018 ; t=-0.123 ; p=0.902)$ and insignificant ( $p$-value greater than 0.1 ) influence on supplier integration. These results suggest that most SMEs in South Africa are not using online IT to collect extensive information about their suppliers for further evaluation. The weak negative path coefficient $(-0.018)$ could be an indication that most surveyed firms are not collecting extensive information about their suppliers for further evaluations and transactions. It is also possible that most of the SMEs surveyed in this study are still trying to determine the importance of further electronic evaluations and transactions of their suppliers before committing themselves to that task. In either case, lower supplier integration is the result.

The fifth hypothesis (H5) of the study postulated that e-informing has a positive influence on supplier integration. As presented in Table 2, H5 was not supported because it had an almost negligible $(\beta=-0.002 ; t=-0.023 ; p=0.982)$ and insignificant ( $p$-value greater than 0.1 ) influence on supplier integration. The assumption commonly made is that the majority of firms always share information with their supply chain partners (Marshall, 2015; Mashiloane, Mafini, \& Pooe, 2018). Whereas this may be true for most firms, the results of the present study indicate a different trajectory. The results show that the sharing of information by using electronic platforms does not impact on the ability of an SME to integrate with its suppliers. The inability to integrate with suppliers, in turn, prevents SMEs from collaborative learning and results in the failure to create strong supplier integration. The lack of a relationship between e-informing and supplier integration could also imply that supply chain member firms share very little information with their business partners or are withholding crucial information, which inhibits higher collaboration amongst supplier firms. Furthermore, because e-informing is not connected to supplier integration, the role of electronic means in the communication between SMEs and suppliers is put to the question. The results may also suggest that although SMEs are distributing information and sharing it with their supply chain members, it is possibly not contributing to supplier collaboration. Overall, the weak relationship may be a result of ineffective information sharing between SMEs and their suppliers, such that the information received is not playing a more significant role in integrating suppliers.

The sixth hypothesis (H6) of the study suggested that supplier integration has a positive and significant relationship with tangible SCP. The results of the study as reflected in Table 2 show that $\mathrm{H} 6$ was supported because a positive and significant path coefficient $(\beta=0.287 ; t=5.000 ; p=0.000)$ validated the hypothesised relationship between the two constructs. Similarly, H7 was validated, as there was a significant positive path coefficient between supplier integration and intangible SCP $(\beta=0.22 ; t=4.810 ; p=0.000)$. The results of this study suggest that supplier integration is critical to improving SCP, especially amongst SMEs. The results are consistent with the suggestions by Bowersox et al. (1999), Thietart (2007), Zhao et al. (2011) and Flynn et al. (2010) that in this dynamic world, firms (especially SMEs) have to cooperate and collaborate with their key suppliers in 
order to survive, compete, prosper, gain competitive advantages and achieve excellence.

\section{Conclusions and managerial implications}

The literature analysed in this study disclosed that e-procurement is one of the most critical developments in SCM in modern times. E-procurement, represented by its five functions - e-sourcing, e-negotiation, e-informing, e-design and e-evaluation - involves the use of technology in facilitating transactions between buyers and suppliers. The literature also revealed the fundamental role of supplier integration in supporting SCP in different forms of enterprises.

The analysis of primary data revealed that the effective implementation of e-design by SMEs enables them to integrate with their suppliers, which further enhances their chances of cutting supply chain costs and improving overall performance. Further analysis of data revealed that the e-negotiation function of e-procurement is also fundamental in stimulating supplier integration in SMEs. However, the study found no relationships existing between supplier integration and three e-procurement functions, namely, e-sourcing, e-evaluations and e-informing. Thus, the study found that the implementation of these three e-procurement functions is disconnected to expectations of improved supplier integration within SMEs. Still, the study found positive connections between supplier integration and both the tangible and intangible dimensions of SCP. This leads to the conclusion that improved supplier integration in SMEs in South Africa leads to improved overall SCP.

The study has some relevant managerial implications. Because positive relationships were found between e-design, e-negotiation and supplier integration, it is vital that steps be taken to improve the implementation of these two e-procurement functions in SMEs. Owners and managers of SMEs should work towards developing a deeper understanding of e-design tools and systems, as this enables them to develop strategies that will contribute to the improvement of supplier integration, which will in turn positively influence SCP. To foster a deeper understanding of e-design systems and tools, greater investments should be made in electronic procurement technologies, as this will create further collaborations. E-negotiation should be recognised as an essential e-procurement function in order to foster ongoing relationships between SMEs and supply chain member firms. It is further important for SME owners and managers to undertake training in e-procurement. Such training should emphasise the importance of e-procurement functions such as e-design and e-negotiation as the critical drivers of supplier integration and SCP. Training can enable SMEs to maximise the benefits of either implementing e-procurement functions effectively or developing healthy supplier relationships.

More sustained integration with suppliers is necessary to ensure that SMEs realise further SCP gains. Such integration with suppliers includes establishing more recent electronic systems for linking SMEs and their suppliers. In addition, where funds are available, supplier relationship management programmes should be launched to foster cooperation and further collaboration with key suppliers.

\section{Contribution of the study}

The present study has some theoretical and practical value. Theoretically, a contribution is made to the existing literature on retail SMEs in South Africa, particularly in the context of developing countries, which is notably limited. This study is one of the few endeavours to investigate the relationship between the five e-procurement dimensions considered in this study, supplier integration and SCP in developing countries. In this manner, the research contributes to new literature and empirical results of these constructs in the context of the retail SME sector. The research is thus likely to be a useful source of reference material for future academic research and further intensify debate amongst researchers in this field.

Practically, the study provides valuable information to SMEs that are considering adopting or have already implemented e-procurement as a tool for enhancing the performance of their supply chains. Overall, these results lend credence to the notion that by investing in supply integration tools and by using e-procurement functions such as e-design and e-negotiation, retail SMEs can improve their own performance. The results of this study are also crucial in that retail SMEs in other regions may refer to them as a benchmark for best practices in SCM and e-procurement practices. The results of this nature can be applied in organisational planning, possibly policymaking and the diagnosis of performance-related problems in the SME sector.

\section{Limitations and possibilities for future research}

The data collected for this research were sourced from only one province, namely, Gauteng. As such, the results of this study could have been more informative if data from SMEs in all nine provinces were included.

Caution must be taken when generalising the results of this study because of the small sample size $(n=283)$ and the use of a non-probability convenience sample (Miguel \& Brito, 2011). In addition, the use of only SME owners and managers as the chief informants in the survey could be a limitation.

Because this study is considered one of the first attempts to investigate the relationship between e-procurement, supplier integration and SCP in Gauteng, South Africa, several possibilities for future research can be suggested.

The study can be extended to non-retail SMEs and larger enterprises. In this study, SCP was measured by tangible and intangible dimensions. Further research could apply different SCP dimensions, such as the SCOR model, output resources and flexibility, amongst others. Because data were only 
collected from SME owners and managers, future research could broaden the scope to include customers, manufacturers (suppliers) and low-level subordinates. E-procurement is a multidimensional concept, and the study only investigated five important dimensions, namely, e-sourcing, e-negotiation, e-informing, e-design and e-evaluation. Future research can consider the use of other e-procurement functions, such as e-payment, e-catalogue, e-tendering, e-tailing, e-purchasing and e-transportation, amongst others.

\section{Acknowledgements}

The authors thank the various owners and managers of SMEs who participated willingly in this study.

\section{Competing interests}

The authors have declared that no competing interests exist.

\section{Authors' contributions}

J.M. collected the data and performed the review of literature. C.M. wrote the research methodology and results sections. M.D. performed the data analysis and made language edits to the article.

\section{Ethical consideration}

This article followed all ethical standards for carrying out research, approved by the Vaal University of Technology HDC310316.

\section{Funding information}

This research received no specific grant from any funding agency in the public, commercial or non-profit sectors.

\section{Data availability statement}

The quantitative data used in this study are available for sharing.

\section{Disclaimer}

The views and opinions expressed in this article are those of the authors and do not necessarily reflect the official policy or position of any affiliated agency of the authors.

\section{References}

Abor, J., \& Quartey, P. (2010). Issues in SME development in Ghana and South Africa. International Research Journal of Finance \& Economics, 39, 218-228.

Amaratunga, D., \& Baldry, D. (2002). Moving from performance to performance management. Facilities, 20(5/6), 217-223. https://doi.org/10.1108/02632770 management

Anderson, J.C., \& Gerbing, D.W. (1988). Structural equation modelling in practice: A review and recommended a two-step approach. Psychological Bulletin, 103(3), 411-423. https://doi.org/10.1037/0033-2909.103.3.411

Antony, A. (2018). Law, democracy and development: The use of e-procurement in South African public procurement law: Challenges and prospects. Law, Democracy \& Development, 22(1), 39-47.

Babbie, E. (2013). The practice of social research (13th edn., International edition) Belmont, CA: Wadsworth.

Baily, P., Farmer, D., Crocker, B., Jessop, D., \& Jones, D. (2008). Procurement principles and management (10th edn.). Harlow: Prentice Hall.
Basheka, B., Oluka, P., \& Mugurisi, P. (2011). Compliance to public procurement reform in developing countries: The conceptual perspective from Uganda. International Journal of Procurement Management, 4(5), 535-548. https://doi. International Journal of Procure
org/10.1504/IJPM.2011.042171

Beamon, R. (1999). Psychometric theory (2nd edn.). New York, NY: McGraw-Hill.

Bhagwat, R., \& Sharma, M.K. (2007). Performance measurement of supply chain management: A balanced scorecard approach. Computers and Industrial Engineering, 53(1), 43-62. https://doi.org/10.1016/j.cie.2007.04.001

Boehmke, B.C., \& Hazen, B.T. (2017). The future of supply chain information systems: The open source ecosystem. Global Journal of Flexible Systems Management, 18(2), 163-168. https://doi.org/10.1007/s40171-017-0152-x

Botta-Genoulaz, V., Campagne, J.P., Llerena, D., \& Pellegrin, C. (2010). Supply chain performance: Collaboration, alignment and coordination. London: John Wiley \& Sons.

Bowersox, D.J., Closs, D.J., \& Stank, T.P. (1999). 21 $1^{\text {st }}$ century logistics: Making supply chain integration a reality. East Lansing, MI: Council of Logistics Management, Michigan State University.

Byrne, B.M. (2013). Structural equation modeling with AMOS: Basic concepts, application and programming. Chicago, IL: Routledge.

Cameron, S. (2007). Making a difference. Journal of Supply Chain Management, 12(3), 50-52.

Cano, J.A., \& Baena, J.J. (2015). Impact of information and communication technologies in international negotiation performance. Review of Business Management, 17(54), 751-768. https://doi.org/10.7819/rbgn.v17i54.1901

Chan, F.T.S., \& Lee, H.J. (2003). Feasibility of performance measurement system for supply chain: A process-based approach and measures. Integrated Manufacturing Systems, 14(3), 179-190. https://doi.org/10.1108/09576060310463145

Chan, F.T.S., \& Qi, H.J. (2003). Feasibility of performance measurement system for supply chain: A process-based approach and measures. Integrated Manufacturing Systems, 14(3), 179-190.

Chang, H.H., \& Wong, K.H. (2012). Adoption of e-procurement and participation of e-marketplace on firm performance: Trust as a moderator. Information \& Management, 47(5-6), 262-270. https://doi.org/10.1016/j.im.2010.05.002

Chang, H.H., Tsai, Y.C., \& Hsu, C.H. (2013). E-procurement and supply chain performance. International Journal of Management, 18(1), 34-51. https://doi. org/10.1108/13598541311293168

Chen, M.C., Yang, T., \& Li, H.C. (2007). Evaluating the supply chain performance of ITbased inter-enterprise collaboration. Information \& Management Journal, 44(6), 524-534. https://doi.org/10.1016/j.im.2007.02.005

Childerhouse, P., \& Towill, D.R. (2003). Simplified material flow holds the key to supply chain integration. The International Journal of Management Science, 31(1), 17-27. https://doi.org/10.1016/S0305-0483(02)00062-2

Chimucheka, T., \& Rungani, E.C. (2011). The impact of inaccessibility to bank finance and lack of financial management knowledge to small, medium and micro enterprises in Buffalo City Municipality, South Africa. African Journal of Business Management, 5(14), 5509-5517.

Chinomona, R., Lin, J., Wang, M., \& Cheng, J. (2010). Soft power and desirable relationship outcomes in Zimbabwe distribution channels. African Journal of Business, 11(2), 20-55. https://doi.org/10.1080/15228916.2010.508997

Corina, P.S. (2011). E-procurement and its contribution to the creation of value added in the supply chain. Journal of Supply Chain Management, 2(2), 63-71.

Das, A., Narasimhan, R., \& Talluri, S. (2006). Supplier integration: Finding an optimal configuration. Journal of Operations Management, 24(5), 563-582. https://doi. org/10.1016/j.jom.2005.09.003

Dennis, A., \& Piatti, D. (2015). African powers of retailing: New horizons for growth. Retrieved from https://www2.deloitte.com/content/dam/Deloitte/ng/Documents/ consumer-business/ng-african-powers-of-retailingnew-horizons-for-growth.pdf

Doern, R. (2009). Investigating barriers to SME growth and development in transition environments: A critique and suggestions for developing the methodology. International Small Business Journal, 27(3), 275-305. https://doi.org/10.1177/ 0266242609102275

Dunn, S.C., Seaker, R.F., \& Waller, M.A. (1994). Latent variables in business logistics research: Scale development and validation. Journal of Business Logistics, 15(2), 145-172.

Fawcett, S.E., Osterhaus, P., Magnan, G.M., Brau, J.C., \& Mccarter, M.W. (2007). Information sharing and supply chain performance: The role of connectivity and willingness. Supply Chain Management: An International Journal, 12(5), 358-368. https://doi.org/10.1108/13598540710776935

Fernandes, T., \& Vieira, V. (2015). Public e-procurement impacts in small -and-medium enterprises. International Journal of Procurement Management, 8(5), 587-607. https://doi.org/10.1504/IJPM.2015.070904

Flynn, A., \& Davis, P. (2016). Investigating the effect of tendering capabilities on SME activity and performance in public contract competitions. International Small Business Journal: Researching Entrepreneurship, 35(4), 449-469. https://doi. org/10.1177/0266242616630035

Flynn, B.B., Hou, B., \& Zhao, X. (2010). The impact of supply chain integration on performance: A contingency and configuration approach. Journal of Operations Management, 28(1), 58-71. https://doi.org/10.1016/j.jom.2009.06.001

Fornell, C., \& Larcker, D.F. (1981). Evaluating structural equation models with unobservable variables and measurement error. Journal of Marketing Research, 18(1), 39-50. https://doi.org/10.1177/002224378101800104

Foster, J., Barkus, E., \& Yavorsky, C. (2006). Understanding and using advanced statistics. Thousand Oaks, CA: Sage. 
Fraering, M., \& Minor, M.S. (2006). Sense of community: An explanatory study of US consumers of financial services. International Journal of Bank Marketing, 24(5) consumers of financial services. International Journal of
284-306. https://doi.org/10.1108/02652320610681738

Frohlich, M.T., \& Westbrook, R. (2001). Arcs of integration: An international study of supply chain strategies. Journal of Operations Management, 19(2), 185-200. https://doi.org/10.1016/S0272-6963(00)00055-3

George, B., Williams, A., \& Henthorne, T. (2011). E-procurement in the hospitality industry: An exploratory study. International Journal of Procurement Management, 3(2), 231-244. https://doi.org/10.1504/IJPM.2011.037384

Georgise, F.B., Thoben, K., \& Seifert, M. (2014). Supply chain Integration in the manufacturing firms in developing country: An Ethiopian case study. Journal of IndustrialEngineering, 2014(251982), 1-13.https://doi.org/10.1155/2014/251982

Germain, R., \& lyer, K.N.S. (2006). The interaction of internal and downstream integration and its association with performance. Journal of Business Logistics, 27(2), 29-52. https://doi.org/10.1002/j.2158-1592.2006.tb00216.x

Gimenez, C., \& Ventura, E. (2005). Supply chain management as a competitive advantage in the Spanish grocery sector. International Journal of Logistics Management, 14(1), 77-88. https://doi.org/10.1108/09574090310806558

Government Gazette. (2003). No 26 National Small Business Amendment Act (vol. 461 pp. 1-10). Cape Town: Parliament of the Republic of South Africa.

Gumboh, J., \& Gichira, R. (2015). Supply chain collaboration among SMEs in Kenya: A review of collaboration barriers. International Journal of Humanities and Socia Science, 5(9), 223-229.

Gunasekaran, A., \& Ngai, E.W.T. (2008). Adoption of e-procurement in Hong Kong: An empirical research. International Journal of Production Economics, 113(1) 159-175. https://doi.org/10.1016/j.ijpe.2007.04.012

Gunasekaran, A., Mcgaughey, R.E., Ngai, E.W.T., \& Rai, B.K. (2009). E-procurement adoption in the South Coast SMEs. International Journal of Production Economics, 122(1), 161-175. https://doi.org/10.1016/j.ijpe.2009.05.013

Gunasekaran, A., Patel, C., \& Tirtiroglu, E. (2001). Performance measures and metrics in a supply chain environment. International Journal of Operations and Production Management, 21(2), 71-87. https://doi.org/10.1108/01443570110358468

Hair, J., Bush, R.P., \& Ortinau, D.J. (2000). Marketing research. Boston, MA: Irwin McGraw Hill.

Hair, J.F., Babin, B.J., Anderson, R.E., \& Tatham, R.L. (2010). Multivariate data analysis. A global perspective (7th edn.). London: Prentice-Hall.

Hair, J.F., Black, W.C., Babin, B.J., \& Anderson, R.E. (2014). Multivariate data analysis (7th edn.). London: Pearson New International Edition.

Hassan, H., Tretiakov, A., Whiddett, D., \& Adon, 1. (2014). Extent of e-procurement use in SMEs: A descriptive study. Procedia - Social and Behavioral Sciences, 164, 264-270. https://doi.org/10.1016/j.sbspro.2014.11.076

Huan, S.H., Sheoran, S.K., \& Wang, G. (2004). A review and analysis of supply chain operations reference (SCOR) model. Supply Chain Management: An International Journal, 9(1), 23-29. https://doi.org/10.1108/13598540410517557

Hugos, M.H. (2011). Essentials of supply chain management (3rd edn.). Hoboken, NJ: John Wiley \& Sons.

Ibem, E.O., \& Laryea, S. (2015). E-procurement use in the South African construction industry. Journal of Information Technology in Construction, 20, 235-386.

Jean, R., Sinkovics, R., \& Cavusgil, S. (2010). Enhancing international customersupplier relationships through IT resources: A study of Taiwanese electronics suppliers. Journal of International Business Studies, 41(7), 1218-1239. https://do org/10.1057/jibs.2010.4

Kim, S.W. (2009). An investigation on the direct and indirect effect of supply chain integration on firm performance. International Journal of Production Economics, 119(2), 328-346. https://doi.org/10.1016/j.ijpe.2009.03.007

Kristal, M.M., Huang, X., \& Roth, A.V. (2010). The effect of an ambidextrous supply chain strategy on combinative competitive capabilities and business performance. Journal of Operations Management, 28(5), 415-429. https://doi.org/10.1016/j jom.2009.12.002

Lau, A.K.W., Yam, R.C.M., \& Tang, E. (2007). The impacts of product modularity on competitive capabilities and performance: An empirical study. Internal Journal of Production Economics, 105(1), 1-20. https://doi.org/10.1016/j.ijpe.2006.02.002

Leboea, S.T. (2017). The factors influencing SME failure in South Africa (Masters dissertation). Cape Town: The Graduate School of Business University of Cape
Town. Retrieved from https://open.uct.ac.za/bitstream/handle/11427/25334/ Town. Retrieved from https://open.uct.ac.za/bitstream/handle/1
thesis_com_2017_leboea_sekhametsi_tshepo.pdf?sequence $=1$

Leopoulous, Y., Kumar, Y.V., \& Sindhu, P. (2007). Benefits of strategic supplier integration in manufacturing industry. Asia Pacific Journal of Research, integration
$3(10), 1-8$

Li, J., \& Li, L. (2005). On the critical success factors for B2B e-marketplace. In Proceedings of the 7th international conference on electronic commerce, Xi'an, pp. 119-122. New York, NY: Association for Computing Machinery.

Li, S., Rangu-Nathan, B., Rangu-Nathan, T.S., \& Rao, S.S. (2006). The impact of supply chain management practices on competitive advantage and organisationa performance.Omega, 34(2), 107-124. https://doi.org/10.1016/j.omega.2004.08.002

Little, T.D. (2013). Longitudinal structural equation modeling. New York, NY: Guilford Press.

Liu, Q., Sun, S.X., Wang, H., \& Zhao, J. (2011). A multi agent-based system for e-procurement exception management. Knowledge Based Systems, 24(1), 49-57. https://doi.org/10.1016/j.knosys.2010.07.004

Lysons, K., \& Farrington, B. (2012). Purchasing and supply chain management (8th edn.). London: Prentice-Hall.
Maiga, A.S. (2016). Assessing the impact of supply chain integration on firm competitive capability. International Journal of Operations Research and Information Systems, 7(1), 1-2. https://doi.org/10.4018/IJORIS.2016010101

Makien, J., Kahkonen, A., \& Lintukangas, K. (2011). E-procurement as a success factor in co-operative purchasing. Journal of Public Procurement Management, 4(1), 56-70. https://doi.org/10.1504/IJPM.2011.037385

Marshall, D.A. (2015). Assessing the value of supply chain information sharing in the new millennium. International Journal of Supply Chain Management, 4(4), 10-21.

Martin, A. (2007). Employee perceptions of organisational commitment, job satisfaction and turnover intensions in a post-merger institution. MCom. dissertation. Johannesburg: University of Johannesburg.

Mashiloane, M.W., Mafini, C., \& Pooe, R.D.I. (2018). Supply chain dynamism, information sharing, inter-organisational relationships and supply chain performance in the manufacturing sector. Acta Commercii, 18(1), a547. https:// doi.org/10.4102/ac.v18i1.547

McCue, C., \& Roma, A. (2012). E-procurement: Myth or reality? Journal for Public Procurement, 5(1), 54-72.

Mettler, T., \& Rohner P. (2009). E-procurement in hospital pharmacies: An explanatory multi-case study from Switzerland. Journal of Theoretical and Applied Electronic Commerce Research, 4(1), 23-38. https://doi.org/10.4067/S0718-18762009000 100004

Miguel, M., \& Brito, S.R. 2011. Toward the development of a supply chain management paradigm: A conceptual framework. Journal of Supply Chain Management, 40(2), 27-37.

Mishra, A.N., \& Agarwal, R. (2010). 'Technological frames, organizational capabilities, and IT use: An empirical investigation of electronic procurement'. Information Systems Research, 21(2), 249-270. https://doi.org/10.1287/isre.1080.0220

Moon, M.J. (2005). E-procurement management in state governments: Diffusion of e-procurement practices and its determinants. Journal of Public Procurement, 5(1), 54-72. https://doi.org/10.1108/JOPP-05-01-2005-B003

Narasimhan, P., \& Peters, S. (2010). Relationship management, global supply chain management. CA, Thousand Oaks: Sage.

Ngui, A.M. (2016). Barriers to e-procurement adoption by small and medium enterprises in Machakos County (Masters dissertation). School of Computing and Informatics, Nairobi: University of Nairobi. Retrieved from https://erepository.uonbi.ac.ke/ bitstream/handle/11295/98353/Mukulungui\%20Angelline_Barriers\%20to\%20 Eprocurement $\% 20$ Adoption $\% 20$ by $\% 20$ Small $\% 20$ and $\% 20$ Medium $\% 20$ Enterprises $\% 20$ in $\% 20$ Machakos $\% 20$ County.pdf?sequence=1\&isAllowed $=y$

Nguyen, T.H. (2009). Information technology adoption in SMEs: An integrated framework. International Journal of Entrepreneurial Behavior \& Research, 15(2), 162-186. https://doi.org/10.1108/13552550910944566

Njagi, M.M., \& Ogutu, M. (2014). Role of supply chain integration on supply chain performance in Kenyan state corporations. International Journal of Current Business and Social Sciences, 1(2), 188-204.

Nugroho, M.A., Susilo, A.Z., Fajar, M.A., \& Rahmawati, D. (2017). Exploratory study of SMES technology adoption readiness factors. Procedia Computer Science, 124 329-336. https://doi.org/10.1016/j.procs.2017.12.162

Ombat, K.O. (2015). The relationship between procurement systems and performance of procurement function in commercial banks in Kenya. International Journal of Economics, Commerce and Management, 3(12), 697-723.

$\mathrm{Ou}, \mathrm{C}$. (2006). Banking and SMEs financing in United States of America. Small business research summary: Conference on International Comparisons in the Financing of research summary: Conference on International Comparisons in the Financing of
SMEs in Developed Nations, Warwick School of Business, 04-05 April 2006. United Kingdom, Coventry: University of Warwick. Retrieved from http://citeseerx.ist. Kingdom, Coventry: University of Warwick. Retrieved from http://cite

Pallant, J. (2007). SPSS survival manual: A step by step guide to data analysis using SPSS for windows (3rd edn.). London: McGraw Hill.

Panayiotou, N.A., Gayialis, S.P., \& Tatsiopoulos, I.P. (2004). An e-procurement system for governmental purchasing. International Journal of Production Economics, 90(1), 79-102. https://doi.org/10.1016/S0925-5273(03)00103-8

Petersen, K.J., Handefield, R.B., \& Ragatz, G.L. (2005). A model of supplier integration into new product development. Journal of Production and Innovation Management, 20(4), 284-299. https://doi.org/10.1111/1540-5885.00028

Presutti, W.D. (2003). Supply management and E-procurement: Creating value added in the supply chain. Industrial Marketing Management, 32(3), 219-226. https:// doi.org/10.1016/S0019-8501(02)00265-1

Pooe, D., Mafini, C., \& Loury-Okoumba, V.W. (2015). The influence of information sharing, supplier trust and supplier synergy on supplier performance: The case of small and medium enterprises. Journal of Transport and
Management, 9(1), 1-15. https://doi.org/10.4102/jtscm.v9i1.187

Pooe, R.I.D., \& Mahlangu, D. (2017). Enhancing SME performance through supply chain integration, collaborative planning, and supply chain capabilities. Journal of chain integration, collaborative planning, and
Contemporary Management, 14, 238-269.

Prajogo, D.I., Oke, A., \& Olhager, J. (2015). Supply chain processes: Linking supply logistics integration, supply performance, lean processes and competitive performance. International Journal of Operations \& Production Management, 30(3), 312-335.

Rinderle-Ma, S. (2005). Towards the automation of E-negotiation process based on web services: A modeling approach. Journal of Procurement Management, 6, 1-12.

Ronchi, S., Brun, A., Golini, R., \& Fan, X. (2010). What is the value of an IT e-procurement system? Journal of Purchasing \& Supply Management, 16(2), 131-140. https:// doi.org/10.1016/j.pursup.2010.03.013

Sakka, O., \& Botta-Genoulaz, V. (2009). A model of factors influencing the supply chain performance (pp. 1-6). INSA de Lyon, LIESP. Retrieved from https://doi.org/ 10.1109/ICCIE.2009.5223796 
Sanders, N. (2007). An empirical study of the impact of e-Business technologies on organizational collaboration and performance. Journal of Operations Management, 25, 1332-1347. https://doi.org/10.1016/j.jom.2007.01.008.

Scot, M., \& Morrison, P. (2007). Towards a structured design of electronic negotiations. New York, NY: Wardsworth Cengage Learning.

Shank, J., \& Brown, D. (2007). Procurement: The missing link in innovation. Supply Chain Management Review, 10(1), 22-28.

Sharma, S. (2012). Supply chain management: Concepts, practices and implementation (2nd edn.). New York, NY: Wardsworth Cengage Learning.

Sibanda, J.J., \& Manda, D.C. (2016). Symptoms of accounting practices that contribute to small business failures in South Africa. Problems \& Perspectives in Management, 14(4), 194-202. https://doi.org/10.21511/ppm.14(4-1).2016.08

Sibindi, A.B., \& Aren, A.O. (2015). Is good corporate governance practice the panacea for small-to-medium businesses operating in the South African retail sector? Corporate Ownership \& Control, 12(2/6), 579-587. https://doi.org/10.22495/ cocv12i2c6p1

Sin, L.Y.M. Tse, A.C.B., Heung, V.C.S., \& Yim, F.H.K. (2005). An analysis of the relationship between market orientation and business performance in the hote industry. Hospitality Management, 24(4), 555-577. https://doi.org/10.1016/j. industry. Hospitality

SME South Africa. (2017). Why SA SMEs can expect better prospects in 2017. Retrieved from https://www.smesouthafrica.co.za/17024/3-reasons-SA-SMEs-can-expecta-better-2017/

Smuts, H. (2008). Determinants of supplier-retailer collaboration: Evidence from an international study. International Journal of Operations and Production Management, 26(1), 24-49. https://doi.org/10.1108/01443570610637003

So, S., \& Sun, H. (2010). Supplier integration strategy for lean manufacturing adoption in electronic-enabled supply chains. Supply Chain Management: An Internationa Journal, 15(6), 474-487. https://doi.org/10.1108/13598541011080455

Srinivasan, M., Mukherjee, D., \& Gaur, A. (2011). Buyer-supplier partnership quality and supply chain performance: Moderating role of risks, and environmental uncertainty. European Management Journal, 29(4), 260-271. https://doi.org/ 10.1016/j.emj.2011.02.004

Statistics South Africa. (Quarter 2: 2015). Quarterly labour force survey. Retrieved from https://www.statssa.gov.za/publications/P0211/P02114thQuarter2016.pdf

Steyn, A.A., \& Leonard, A.C. (2012). Guidance for SMEs with the adoption of technology: A conceptual framework. South African Journal of Entrepreneurship and Small Business Management, 5(1), 24-33. https://doi.org/10.4102/sajesbm.v5i1.25

Tabachnick, B.G., \& Fidell, L.S. (2007). Using multivariate statistics (5th edn.). Boston, MA: Pearson Education.

Tatsis, V., Mena, C. Van Wassenhove, L., \& Whicker, L. 2006. E-procurement in the Greek food \& drink industry: Drivers \& impediments. Journal of Purchasing and Supply Management, 12(2),63-74. https://doi.org/10.1016/j.pursup.2006.04.003
Thietart, T. (2007). A resource-based perspective on information technology capability and firm performance: An empirical investigation. MIS Quarterly, 24(1), 169-196. https://doi.org/10.2307/3250983

Urban, B., \& Naidoo, R. (2012). Business sustainability: Empirical evidence on operational skills in SMEs in South Africa. Journal of Small Business and Enterprise Development, 19(1), 146-163. https://doi.org/10.1108/14626001211196451

Vaast, E., \& Walsham, G. (2017). Trans-situated learning: Supporting a network of practice with an information infrastructure. Information Systems Research, 20(4) 547-564. https://doi.org/10.1287/isre.1080.0228

Walters, S. (2009). Procurement performance indicators guide using procurement performance indicators to strengthen the procurement process for public health commodities. Journal of Public Health and Safety, 12, 1-48.

Wegner, T. (2012). Applied business statistics: Methods and excel-based applications (3rd edn). Cape Town: Juta.

Wisner, J.D., Tan, K.C., \& Leong, G.K. (2012). Supply chain management: A balanced approach (3rd edn.). New York, NY: Cengage Learning.

Wong, A.S.H., Tjosvold, D., \& Yu, Z.Y. (2005). Organisational partnerships in China: Selfinterest, goal independence and opportunism. Journal of Applied Psychology, 90(4), 782-791. https://doi.org/10.1037/0021-9010.90.4.782

$\mathrm{Wu}, \mathrm{F}$. (2007). Antecedents and outcomes of E-procurement adoption: An integrative model. IEEE Transactions on Engineering Management, 54(3), 576-590. https://doi.org/10.1109/TEM.2007.900786

Yu, W., Chavez, R., Feng, M., \& Wiengarten, F. (2014). Integrated green supply chain management and operational performance. Supply Chain Management An International Journal, 19(5/6), 683-696. https://doi.org/10.1108/SCM-072013-0225

Zarenda, H. (2013). South Africa's National Development Plan and its implications for regional development. Tralac Working Paper D13WP012013. Retrieved from https://www.tralac.org/files/2013/07/D13WP012013-Zarenda-South-AfricasNDP-and-implications-for-regional-development-20130612-fin.pdf.

Zhao, G., Feng, T., \& Wang, D. (2015). Is more supply chain integration always beneficial to financial performance? Industrial Marketing Management Journal, 45, 162-172. https://doi.org/10.1016/j.indmarman.2015.02.015

Zhao, X., Huo, B., Selen, W., \& Yeung, J.H.Y. (2011). The impact of relationship commitment on the integration between manufacturers and customers in supply chain. Journal of Operations Management, 29(1-2), 368-388. https://doi.org/10.1016/j.jom.2007.08.002

Zhao, L., Huo, B., Sun, L., \& Zhao, X. (2013). The impact of supply chain risk on supply chain integration and company performance: A global investigation. International Journal of Supply Chain Management, 18(2), 115-131. https://doi.org/ 10.1108/13598541311318773

Zheng, J., Bakker, E., Knight, L., Gilhespy, H., Harland, C., \& Walker, H. (2016). A strategic case for e-adoption in healthcare supply chains. International Journal of Informatio Management, 26(4), 290-301. https://doi.org/10.1016/j.ijinfomgt.2006.03.010 